\title{
Assessment of Injury to Fish and Wildlife Resources in the Grand Calumet River and Indiana Harbor Area of Concern, USA
}

\author{
D. D. MacDonald, ${ }^{1}$ C. G. Ingersoll, ${ }^{2}$ D. E. Smorong, ${ }^{1}$ R. A. Lindskoog, ${ }^{1}$ D. W. Sparks, ${ }^{3}$ J. R. Smith, ${ }^{4}$ T. P. Simon, ${ }^{3}$ \\ M. A. Hanacek ${ }^{1}$ \\ ${ }^{1}$ MacDonald Environmental Sciences Ltd., \#24-4800 Island Highway North, Nanaimo, British Columbia V9T 1W6, Canada \\ ${ }^{2}$ Columbia Environmental Research Center, U.S. Geological Survey, 4200 New Haven Road, Columbia, Missouri 65201, USA \\ ${ }^{3}$ U.S. Fish and Wildlife Service, 620 South Walker Street, Bloomington, Indiana 47403, USA \\ ${ }^{4}$ Indiana Department of Environmental Management, 100 North Senate Avenue, P.O. Box 6015, Indianapolis, Indiana 46206-6015, USA
}

Received: 6 February 2001/Accepted: 7 January 2002

\begin{abstract}
This article is the second in a series of three that describes the results of a Natural Resource Damage Assessment (NRDA) conducted in the Grand Calumet River and Indiana Harbor Area of Concern (IHAOC). The assessment area is located in northwest Indiana and was divided into nine reaches to facilitate the assessment. This component of the NRDA was undertaken to determine if fish and wildlife resources have been injured due to exposure to contaminants that are associated with discharges of oil or releases of other hazardous substances. To support this assessment, information was compiled on the chemical composition of sediment and tissues; on the toxicity of whole sediments, pore water, and elutriates to fish; on the status of fish communities; and on fish health. The data on each of these indicators were compared to regionally relevant benchmarks to assess the presence and extent of injury to fish and wildlife resources. The results of this assessment indicate that injury to fish and wildlife resources has occurred throughout the assessment area, with up to five distinct lines of evidence demonstrating injury within the various reaches. Based on the frequency of exceedance of the benchmarks for assessing sediment and tissue chemistry data, total polychlorinated biphenyls is the primary bioaccumulative contaminant of concern in the assessment area. It is important to note, however, that this assessment was restricted by the availability of published bioaccumulation-based sediment quality guidelines, tissue residue guidelines, and other benchmarks of sediment quality conditions. The availability of chemistry data for tissues also restricted this assessment in certain reaches of the assessment area. Furthermore, insufficient information was located to facilitate identification of the substances that are causing or substantially contributing to effects on fish (i.e., sediment toxicity, impaired fish health, or impaired fish community structure). Therefore, substances not included on the list of COCs cannot necessarily be considered to be of low priority with respect to sediment injury (e.g., metals, polycyclic aromatic hydrocarbons, alkanes, alkenes, organochlorine pesticides, phthalates, dioxins, and furans, etc.).
\end{abstract}

Correspondence to: D. D. MacDonald; email: mes1@island.net
The Grand Calumet River system is a relatively small drainage basin that flows through northwestern Indiana and northeastern Illinois. Information from a number of sources indicates that the Grand Calumet River drainage basin is one of the most highly industrialized areas in the United States (Bright 1988; Brannon et al. 1989; Ryder 1993). MacDonald et al. (2002) described the point and non-point contaminant sources in this watershed. To address concerns associated with the widespread contamination of surface waters and sediments, the International Joint Commission designated the Grand Calumet RiverIndiana Harbor complex as an Area of Concern (IHAOC) under the Great Lakes Water Quality Agreement (IJC 1989).

Concerns regarding historic discharges of oil and releases of other hazardous substances led the United States Fish and Wildlife Service (U.S. FWS) and the State of Indiana (the trustees) to initiate a Natural Resource Damage Assessment (NRDA) of the Grand Calumet River (GCR; which includes two reaches on the East Branch [EB] and two reaches on the West Branch [WB] of the river; i.e., EBGCR-I, EBGCR-II, WBGCR-I, WBGCR-II), U.S. Canal (USC), Indiana Harbor Canal (IHC), Lake George Branch (LGB), Indiana Harbor (IH), and waters of nearshore Lake Michigan (LM; i.e., the assessment area; see MacDonald et al. 2002 for a map of the assessment area; Natural Resources Trustees 1997). As described in the assessment plan for the NRDA (Natural Resources Trustees 1997) and mandated under the Comprehensive Environmental Response, Compensation, and Liability Act, the Oil Pollution Act, and the Clean Water Act, the trustees are documenting the cumulative injuries resulting from exposure to multiple contaminants (i.e., arising from discharges of oil and releases of other hazardous substances) and to determine the appropriate scope and scale of restoration and compensation (Natural Resources Trustees 1997). As identified by the Natural Resources Trustees (1997), the primary chemicals of potential concern (COPCs) were polychlorinated biphenyls (PCBs), oils and oil-related compounds (including alkanes, alkenes, naphthalenes, and polyaromatic hydrocarbons 
[PAHs]), and metals. Based on the activities that have been conducted in the assessment area, various pesticides, cyanide, phenols, and conventional variables - such as total organic carbon (TOC), dissolved oxygen (DO), sediment oxygen demand (SOD), and unionized ammonia $\left(\mathrm{NH}_{3}\right)$-were identified as additional COPCs.

This investigation was conducted to support the NRDA of the assessment area by (1) determining if discharges of oil or releases of other hazardous substances have injured or are likely to have injured fish and wildlife resources (i.e., fish, amphibians, reptiles, birds, or mammals) within the assessment area; and (2) identifying contaminants of concern (COCs; i.e., those substances that are causing or substantially contributing to sediment injury) in the assessment area. Definitions of injury to natural resources are provided by MacDonald et al. (2002). The indicators of injury to fish and wildlife resources that were used in this investigation included toxicity to fish, fish community structure, sediment fish health, chemistry, and tissue chemistry. An evaluation of injury to sediments and sedimentdwelling organisms was also conducted and is presented in the first manuscript in this series (MacDonald et al., 2002). The third manuscript in the series will describes the results of an assessment of sediment toxicity that was recently conducted in the assessment area.

\section{Materials and Methods}

\section{Description of the Assessment Area}

This investigation was focused on the GCR, IHC, IH, and associated LM environments (Figure 1). The riparian and upland habitats closely associated with these waters were also considered in this assessment, including lands within the boundaries of the Indiana Dunes National Lakeshore. A description of the assessment area is provided by MacDonald et al. (2002).

\section{Identification of Key Indicators of Sediment Quality Conditions}

This assessment, which was conducted in accordance with the Department of the Interior regulations (US DOI 1996), was undertaken to determine if fish and wildlife resources within the assessment area have been injured by discharges of oil or releases of other hazardous substances from industrial, municipal, and nonpoint sources. To support this assessment, a suite of five indicators of sediment quality conditions was identified that could be used to assess injury to fish and wildlife resources, including sediment toxicity, fish health, fish community status, sediment chemistry, and tissue chemistry.

Sediment Toxicity Tests: In this investigation, the results of toxicity tests with fish were considered to be a primary indicator of injury to fish and wildlife resources. More specifically, demonstration of toxicity to fish was considered to provide the necessary evidence to conclude that contaminated sediments have the potential to adversely affect fish in the assessment area. The toxicity tests that were used in this evaluation included 10-day elutriate and 4- to 12-day whole sediment toxicity tests with fathead minnow (Pimephales promelas; endpoints: survival and growth; Lucas and Steinfeld 1972; Burton 1994; Gillespie et al. 1998). Sediment samples were designated as toxic to fish if the response of the test organism exposed to IHAOC sediments was reported to be significantly different from the response that was observed in an appropriately selected control or reference sediment.

Fish Health: Data on fish health provide important information for determining if fish have been adversely affected by discharges of oil or releases of other hazardous substances. Fish health represents a relevant indicator of sediment quality conditions because fish that are exposed to contaminated sediment can exhibit impaired health, such as an increased incidence of tumors (Malins et al. 1985; Goyette et al. 1988; Payne et al. 1988). In turn, impaired fish health can result in increased rates of fish mortality and associated effects on fish populations and fish communities. In this investigation, the incidence of deformities, fin erosion, lesions, and tumors (i.e., DELT abnormalities) in fish was used as an important indicator of injury to fish and wildlife resources (Sobiech et al. 1994). Information on the health of fish utilizing habitats within the IHAOC was obtained from several studies, including Simon (1993), Sobiech et al. (1994), Simon and Stewart (1998), and Simon et al. (2000). Fish health was considered impaired if the incidence of DELT abnormalities was $>1.3 \%$, which was the incidence of abnormalities that was observed in the most impacted sites within the Central Corn Belt Plain ecoregion (Simon 1991; Sobiech et al. 1994).

Status of Fish Communities: Data on the status of fish populations and fish communities provides important information for assessing injury to fish and wildlife resources. In this investigation, index of biotic integrity (IBI) scores were used as primary indicators of the status of fish communities and, hence, injury to fish and wildlife resources. The IBI integrates information on species composition (i.e., total number of species; number of three key groups of species, including darter/ sculpin/madtom, sunfish, and minnow species; types of species; number of sensitive species; and percent tolerant species), on trophic composition (i.e., percent omnivores, percent insectivores, and percent pioneer species), and on fish condition (i.e., catch per unit effort, percent simple lithophils, and percent DELT abnormalities; Simon 1991). Based on calibration of the IBI for use in the Central Corn Belt Plains ecoregion (Simon 1991), which contains the IHAOC, fish communities were considered to be impaired at IBI scores of $\leq 34$ (which is the upper limit of the range of scores for fish communities that are classified as having poor integrity). In Indiana, waters with IBI scores of $\leq 34$ are considered to only partially support or not support beneficial uses as defined in the Indiana Clean Water Report (IDEM 2000). By comparison, the mean IBI score for the Eastern Corn Belt Plains ecoregion was $44 \pm 12$ (OEPA 1988). Therefore, the threshold for fish community impairment (i.e., IBI score of $\leq 34$ ) is similar to the benchmarks that have been used to evaluate the integrity of fish populations elsewhere in Indiana and the midwest.

Information on the status of fish communities in the IHAOC (i.e., IBI scores) were obtained from several sources including Simon (1993), Sobiech et al. (1994), Simon and Stewart (1998), Stewart et al. (1999), and Simon et al. (2000). In each of these studies, the nearshore margins along both stream banks were sampled, using electroshocking equipment, over a distance of $500 \mathrm{~m}$. All fish netted were identified to species, measured for length, and enumerated in the field. Larger individuals were assessed for DELT abnormalities. The resultant data were compiled and used to calculate IBI scores for each river reach sampled.

Sediment Chemistry: In addition to causing direct effects on aquatic biota, contaminants can also accumulate in the tissues of sedimentdwelling organisms and, in so doing, adversely affect wildlife species that consume aquatic organisms. Bioaccumulation-based sediment quality guidelines (SQGs) have been developed to determine the concentrations of individual chemicals or classes of chemicals in sediments that will not result in unacceptable levels of that substance in the tissues of aquatic organisms (Ingersoll et al. 1997). In this 


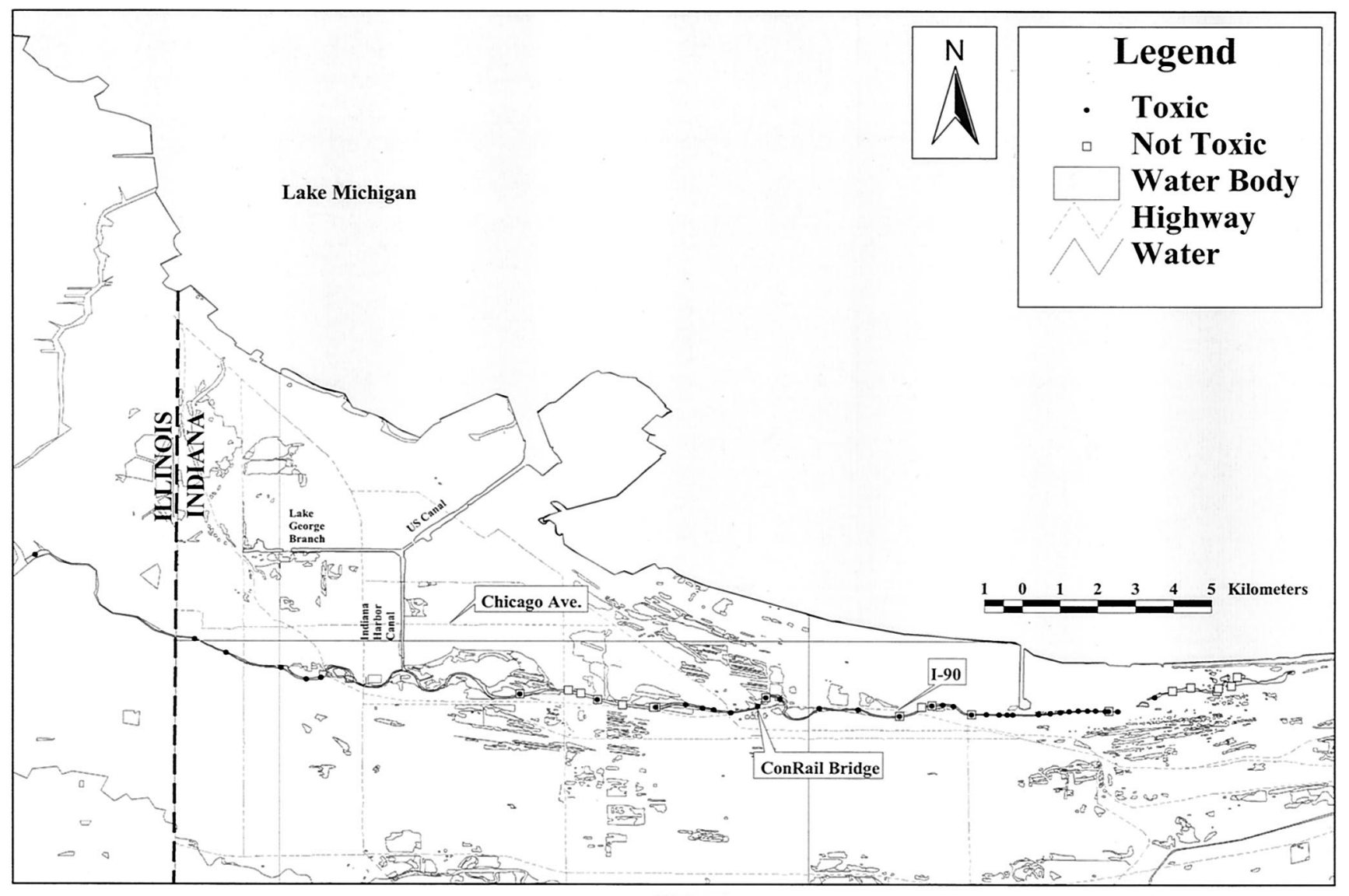

Fig. 1. Extent of sediment and elutriate toxicity to fathead minnows (Pimephales promelas) in the assessment area

investigation, sediment chemistry data (i.e., organic carbon-normalized concentrations of total PCBs and organochlorine pesticides) were compared to the bioaccumulation-based SQGs for the protection of piscivorus wildlife that have been developed by the New York State Department of Environmental Conservation (NYSDEC 1999). The presence of elevated levels of contaminants in sediments, relative to the SQGs, was considered to be indicative of sediment injury relative to fish-eating wildlife species in the assessment area (i.e., contaminated sediments pose a hazard to piscivorus wildlife due to the potential for bioaccumulation in the food web). The sediment chemistry data used in this evaluation were obtained from 30 studies conducted within the IHAOC between 1979 and 1999, the results of which are reported by MacDonald and Ingersoll (2000a, 2000b).

Tissue Chemistry: Data on the concentrations of COPCs in the tissues of aquatic organisms provides important information for assessing the extent to which bioaccumulative substances have accumulated in the tissues of sediment-dwelling species and fish. Comparison of these data to tissue residue guidelines (TRGs) provides a basis for determining if contaminants have accumulated in the tissues of aquatic organisms to such an extent that adverse effects on piscivorus wildlife species are likely to occur. In this investigation, the available tissue residue data were compared to the TRGs for the protection of piscivorus wildlife that have been developed by NYSDEC (Newell et al. 1987) and the Canadian Council of Ministers of the Environment (CCME 1999). The presence of elevated levels of contaminants in tissues relative to the TRGs was considered to indicate the potential for adverse effects on fish-eating wildlife species in the assessment area. Information on the levels of bioaccumulative substances in the tissues of fish and aquatic invertebrates were obtained from nine studies conducted in the IHAOC between 1982 and 1999, the results of which are reported by MacDonald and Ingersoll (2000a, 2000b).

\section{Acquisition and Evaluation of Sediment Quality Data and Related Information}

To support this assessment, several types of data were acquired and evaluated. First, information on the toxicity of whole sediments and elutriates to fish was assembled for the assessment area. Information on fish health and fish community structure was also compiled from studies that had been conducted within the IHAOC. Furthermore, the available information on the chemical composition of whole sediments was compiled for both surficial and subsurface sediment samples (samples from all sediment depths were used in this analysis to evaluate potential exposures that could occur if surficial sediments are removed). Surficial sediment samples were those that were collected from the sediment-water interface to any depth (e.g., the first sample from a sediment core or a sample from a grab sampler); subsurface sediment samples included any other samples (e.g., subsequent samples from a sediment core). Finally, the available information on the levels of COPCs in the tissues of invertebrates and fish was assembled.

Information on the physical, chemical, biological, and toxicological characteristics of environmental media from the assessment area was obtained from a number of sources. First, more than 10 bibliographic databases were searched to identify candidate data sets. Next, more than 300 scientists active in the sediment quality assessment field were 
contacted to acquire the most recent information on freshwater sediments. Finally, U.S. Department of Justice, U.S. Environmental Protection Agency, U.S. FWS, and Indiana Department of Environmental Management (IDEM) staff provided a number of reports and data sets applicable to the study area.

Because the acquired studies had been conducted for different reasons and employed a variety of methods, all of the candidate data sets that were considered for use in this assessment (i.e., from the IHAOC) were critically evaluated. The acceptance criteria that were applied to individual studies provided a basis for determining if experimental designs, measurement endpoints, sample collection and handling procedures, toxicity testing protocols, environmental conditions, control responses, and analytical methods were consistent with established procedures (MacDonald and Ingersoll 2000b). All of the data that met the acceptance criteria were incorporated into the project database and published in MacDonald and Ingersoll (2000b; available online at http://midwest.fws.gov/grandcalumetriver).

A relational project database was developed in Microsoft Access format to support the compilation and subsequent analysis of the assembled information. All of the sediment chemistry and fish tissue residue data compiled in the database were georeferenced to facilitate mapping and spatial analysis using geographic information systembased applications (i.e., ESRI's ArcView and Spatial Analyst software). The data compiled in the database were verified against the original data source to ensure data quality. For data acquired electronically, a minimum of $10 \%$ of the data were compared to source files. For data that were compiled from hard-copy materials (i.e., reports and journal articles), $100 \%$ of the data were compared to the source documents.

\section{Data Treatment}

To support subsequent interpretation of the sediment chemistry data, the total concentrations of several chemical classes were determined for each sediment sample. Specifically, for PCBs the concentrations of total PCBs were determined using various procedures, depending on how the data were reported in the original study. If only the concentrations of total PCBs was reported in the study, then those values were used directly. If the concentrations of various Aroclors (e.g., Aroclor 1242, Aroclor 1248) were reported, then the concentrations of the various Aroclors were summed to determine the concentration of total PCBs. When the concentrations of individual congeners were reported, these values were summed to determine total PCB concentrations. For DDTs, the concentrations of $\mathrm{p}, \mathrm{p}^{\prime}-\mathrm{DDD}$ and $\mathrm{o}, \mathrm{p}^{\prime}$-DDD, $\mathrm{p}, \mathrm{p}^{\prime}$-DDE and $o, p^{\prime}$-DDE, and $p, p^{\prime}$-DDT and o, $p^{\prime}$-DDT were summed to calculate the concentrations of sum DDD, sum DDE, and sum DDT, respectively. Total DDTs was calculated by summing the concentrations of sum DDD, sum DDE, and sum DDT. Finally, the concentrations of total chlordane were determined by summing the concentrations of alphaand gamma-chlordane isomers. If only the concentrations of total chlordane were reported in the study, then those values were used directly. In calculating the total concentrations of the various chemical classes, less than detection limit values were assigned a value of one-half of the detection, except when the detection limit was greater than the consensus-based probable effect concentration PEC, or an alternate SQG if a PEC was not available; MacDonald et al. 2000). In this latter case, the less than detection limit value was not used in the calculation of the total concentration of the substance.

\section{Evaluation of Sediment Injury}

Discharges of oil and releases of other hazardous substances into aquatic ecosystems have the potential to cause injury to biological resources (Natural Resources Trustees 1997). Contaminated sediments pose a hazard to fish or wildlife when concentrations of one or more contaminants exceed biological response thresholds. In this investigation, an injury to sediments has been identified if the measured concentrations of contaminants in sediments or tissues were sufficient to adversely affect fish or wildlife resources, or if direct effects have been demonstrated on biological resources. Specifically, injury to fish or wildlife was established by documenting the presence of any of the following conditions.

- Acute or chronic mortality, reduced growth, impaired reproduction, or abnormal development of fish (as indicated by the results of laboratory toxicity tests; US EPA 2000; ASTM 2001)

- Altered organ morphology, increased incidence of tumors/lesions, or degraded health of fish (as indicated by the results of field surveys; e.g., increased incidence of DELT abnormalities; Simon 1991; Sobiech et al. 1994)

- Degraded or depressed fish populations or altered fish communities (as indicated by the results of field surveys; Simon 1991)

- Sediment quality conditions sufficient to adversely affect wildlife species due to the accumulation of contaminants in the tissues of prey species (i.e., fish or invertebrates; as indicated by concentrations of PCBs, organochlorine pesticides, and/or polychlorinated dibenzo- $p$-dioxins/furans [PCDDs/PCDFs] in whole sediment that exceeded the bioaccumulation-based SQGs; NYSDEC 1999)

- Accumulation of contaminants in the tissues of aquatic organisms to levels that could injure piscivorus wildlife species (as indicated by concentrations of PCBs, organochlorine pesticides, and/or PCDDs/ PCDFs that exceeded TRGs; Newell et al. 1987; CCME 1999)

For each indicator, evidence from at least two samples from different locations (separated by a straight-line distance of not less than 100 feet) was required to conclude that sediment quality conditions within a specific reach were sufficient to adversely affect fish and wildlife resources (Natural Resources Trustees 1997). Within each reach, evidence of injury for any one of the indicators was considered to be sufficient to conclude that injury to fish and wildlife resources had occurred within a particular reach of the assessment area.

\section{Identification of COCs}

In this investigation, COCs are defined as those substances that occur in sediments at concentrations that are sufficient to cause or substantially contribute to injury to fish and wildlife resources. The COCs were identified by comparing the concentrations of each substance that have been measured in sediments to the corresponding chemical benchmarks. The chemical benchmarks that were used in this evaluation included the published bioaccumulation-based SQGs (NYSDEC 1999) and the TRGs for the protection of piscivorus wildlife (Newell et al. 1987; MacDonald and Ingersoll 2000a). Those substances that occurred in sediments and/or tissues within the various reaches of the assessment area (i.e., in two or more samples) at concentrations in excess of the chemical benchmarks were identified as COCs.

\section{Results and Discussion}

Information of the toxicity of whole sediments, pore water, or elutriates to fish (fathead minnows; $P$. promelas) was available for four reaches within the assessment area, including the GCL, EBGCR-I, EBGCR-II, and WBGCR-II (Table 1). The results of these laboratory toxicity tests demonstrate that sediments from the EBGCR-I, EBGCR-II, and WBGCR-II are frequently acutely toxic to fish in 4- to 10-day exposures (Figure 2). 
Table 1. Summary of assessment of effects on fish and wildlife resources

\begin{tabular}{|c|c|c|c|c|c|c|}
\hline \multirow[b]{2}{*}{ Reach } & \multicolumn{5}{|c|}{ Indicator of Injury on Fish and Wildlife Resources ${ }^{\mathrm{a}}$} & \multirow{2}{*}{$\begin{array}{l}\text { \# of Lines of } \\
\text { Evidence } \\
\text { Demonstrating } \\
\text { Injury to Fish } \\
\text { and Wildlife } \\
\text { Resources }\end{array}$} \\
\hline & $\begin{array}{l}\text { Toxicity to } \\
\text { Fish }^{\mathrm{b}}\end{array}$ & Fish Health ${ }^{\mathrm{c}}$ & $\begin{array}{l}\text { Fish } \\
\text { Community }^{\mathrm{d}}\end{array}$ & $\begin{array}{l}\text { Whole } \\
\text { Sediment } \\
\text { Chemistry }\end{array}$ & $\begin{array}{l}\text { Tissue } \\
\text { Chemistry }^{\mathrm{f}}\end{array}$ & \\
\hline Grand Calumet Lagoons & $14 \%(\mathrm{n}=7)$ & $0 \%(\mathrm{n}=12)$ & $38 \%(\mathrm{n}=13)^{*}$ & $84 \%(\mathrm{n}=58)^{*}$ & $100 \%(\mathrm{n}=18)^{*}$ & 3 \\
\hline $\begin{array}{l}\text { East Branch Grand Calumet } \\
\text { River-I } \\
\text { East Branch Grand Calumet }\end{array}$ & $57 \%(\mathrm{n}=23)^{*}$ & $40 \%(\mathrm{n}=10)^{*}$ & $100 \%(\mathrm{n}=29)^{*}$ & $74 \%(\mathrm{n}=110)^{*}$ & $100 \%(\mathrm{n}=22)^{*}$ & 5 \\
\hline $\begin{array}{l}\text { River-II } \\
\text { West Branch Grand Calumet }\end{array}$ & $85 \%(\mathrm{n}=40)^{*}$ & $75 \%(n=4) *$ & $100 \%(\mathrm{n}=22)^{*}$ & $66 \%(\mathrm{n}=90)^{*}$ & $100 \%(\mathrm{n}=5)^{*}$ & 5 \\
\hline $\begin{array}{l}\text { River-I } \\
\text { West Branch Grand Calumet }\end{array}$ & $\mathrm{ID}(\mathrm{n}=0)^{\mathrm{g}}$ & $100 \%(\mathrm{n}=3)^{*}$ & $100 \%(\mathrm{n}=12)^{*}$ & $29 \%(\mathrm{n}=7)^{*}$ & $100 \%(\mathrm{n}=7)^{*}$ & 4 \\
\hline $\begin{array}{l}\quad \text { River-II } \\
\text { Indiana Harbor Canal } \\
\text { Lake George Branch } \\
\text { US Canal }\end{array}$ & $\begin{array}{c}100 \%(\mathrm{n}=7)^{*} \\
\text { ID }(\mathrm{n}=0) \\
\text { ID }(\mathrm{n}=0) \\
\text { ID }(\mathrm{n}=0)\end{array}$ & $\begin{array}{r}100 \%(\mathrm{n}=1) \\
33 \%(\mathrm{n}=3) \\
50 \%(\mathrm{n}=2) \\
50 \%(\mathrm{n}=2)\end{array}$ & $\begin{array}{c}100 \%(\mathrm{n}=17)^{*} \\
100 \%(\mathrm{n}=4)^{*} \\
50 \%(\mathrm{n}=2) \\
100 \%(\mathrm{n}=8)^{*}\end{array}$ & $\begin{array}{l}18 \%(\mathrm{n}=17)^{*} \\
93 \%(\mathrm{n}=15)^{*} \\
83 \%(\mathrm{n}=29)^{*} \\
84 \%(\mathrm{n}=37)^{*}\end{array}$ & $\begin{aligned} & 100 \%(\mathrm{n}=5)^{*} \\
& 100 \%(\mathrm{n}=7)^{*} \\
& \operatorname{ID}(\mathrm{n}=0) \\
& 100 \%(\mathrm{n}=18)^{*}\end{aligned}$ & $\begin{array}{l}4 \\
3 \\
1 \\
3\end{array}$ \\
\hline $\begin{array}{l}\text { Indiana Harbor/Lake } \\
\text { Michigan } \\
\text { Overall }\end{array}$ & $\begin{aligned} \text { ID }(\mathrm{n} & =0) \\
71 \%(\mathrm{n} & =77) *\end{aligned}$ & $\begin{aligned} 100 \%(\mathrm{n} & =1) \\
39 \%(\mathrm{n} & =38)^{*}\end{aligned}$ & $\begin{aligned} 100 \%(\mathrm{n} & =1) \\
92 \%(\mathrm{n} & =108)^{*}\end{aligned}$ & $\begin{array}{l}88 \%(\mathrm{n}=33)^{*} \\
74 \%(\mathrm{n}=396)^{*}\end{array}$ & $\begin{array}{l}86 \%(\mathrm{n}=21)^{*} \\
97 \%(\mathrm{n}=103)^{*}\end{array}$ & $\begin{array}{l}2 \\
5\end{array}$ \\
\hline
\end{tabular}

${ }^{a}$ For each line of evidence, sediment injury is indicated if two or more samples have conditions sufficient to cause or substantially contribute to sediment injury. Evidence of sediment injury is denoted with an asterisk $(*)$.

${ }^{\mathrm{b}}$ Percent of sediment samples that were toxic to fish in laboratory tests.

${ }^{\mathrm{c}}$ Percent of fish samples with $>1.3 \%$ DELT abnormalities.

${ }^{\mathrm{d}}$ Percent of fish samples with IBI scores of $\leq 34$ (i.e., poor, very poor, or no fish).

e Percent of sediment samples with one or more chemical concentrations in excess of the bioaccumulation SQGs for wildlife.

${ }^{\mathrm{f}}$ Percent of fish and invertebrate tissue samples with one or more chemical concentrations in excess of the TRGs for wildlife.

${ }^{\mathrm{g}} \mathrm{ID}=$ insufficient data; $\mathrm{n}=$ number of samples.

Overall, 55 of the 77 samples $(71 \%)$ that were tested were shown to be toxic to fish (Table 1). The incidence of sediment toxicity ranged from $14 \%$ in the GCL to $100 \%$ in the WBGCR-II (Table 1). Only one sample from the GCL was toxic to fish, which indicates that conditions sufficient to cause acute toxicity to fish were observed only in the West Lagoon.

The available information on incidence of DELT abnormalities indicated that fish health has been compromised in the assessment area (i.e., relative to other riverine sites in the Central Corn Belt Plain ecoregion; Table 2). Based on the information that was compiled, fish health has been compromised in several of the reaches, including EBGCR-I, EBGCRII, and WBGCR-I (Simon 1993; Sobiech et al. 1994; Simon and Stewart 1998; Simon et al. 2000). The average incidence of DELT abnormalities ranged from $0 \%$ in the GCLs to $12.8 \%$ in IH/LM (Table 2). The highest incidence of DELT abnormalities $(17.4 \%$ ) was observed in the EBGCR-II (Table 2).

A number of field surveys have been conducted over the past 15 years to evaluate the status of fish communities in the assessment area (Simon et al. 1989, 2000; Simon and Moy 1997; Sobiech et al. 1994; Simon 1993; Simon and Stewart 1998). The results of these surveys demonstrate that the integrity of fish communities has been impaired, relative to reference sites in the Central Corn Belt Plain ecoregion, in all of the reaches that have been sufficiently examined. Overall, 99 of the 108 samples that have been collected had characteristics that were indicative of impaired fish communities (Table 3). The IBI scores ranged from 0 to 43 in the various stream reaches, which classifies fish communities as no fish, very poor, poor, or fair (Simon 1991). The lowest average IBI scores were reported for the IH/LM (14.0; $\mathrm{n}=1)$, WBGCR-II $(15.9 \pm 9.8$; $\mathrm{n}=17)$, WBGCR-I $(16.5 \pm 10.4 ; \mathrm{n}=12)$, and IHC $(17.5 \pm$ $4.4 ; n=4)$. Based on these IBI scores, the integrity of fish communities in these four reaches would be classified as very poor. Somewhat higher average IBI scores were reported for the EBGCR-I, EBGCR-II, LGB, and USC; average IBI scores in these reaches ranged from 22.8 to 26.0. As such, fish communities in these four reaches would be classified as having poor to very poor integrity. Within the LGB, the wetland areas that are located to the west of the Lake George Canal had the highest IBI score (38; Simon et al. 2000). Relatively higher IBI scores were also reported for the GCL, with IBI scores ranging from 31 to 43 (mean IBI score of $38.1 \pm 5.0 ; n=13$ ). In the GCL, the lowest IBI scores (i.e., 31 to 38) were reported for the West Lagoon (classified as having poor to fair-poor integrity; located closest to an iron and steel manufacturer's slag landfill; Simon and Stewart 1998). In contrast, IBI scores for three of the other GCL segments were 42 to 43 , indicating fish communities with fair integrity. These data show that the assessment area is capable of supporting fish communities that are similar to those that have been observed in the Central Corn Belt Plain ecoregion (Simon 1991). However, fish communities with fair or better integrity have been observed only rarely within the assessment area (MacDonald and Ingersoll 2000a, 2000b).

The potential for injury to fish and wildlife resources was also evaluated using sediment chemistry data. More specifically, the measured concentrations of bioaccumulative sub- 


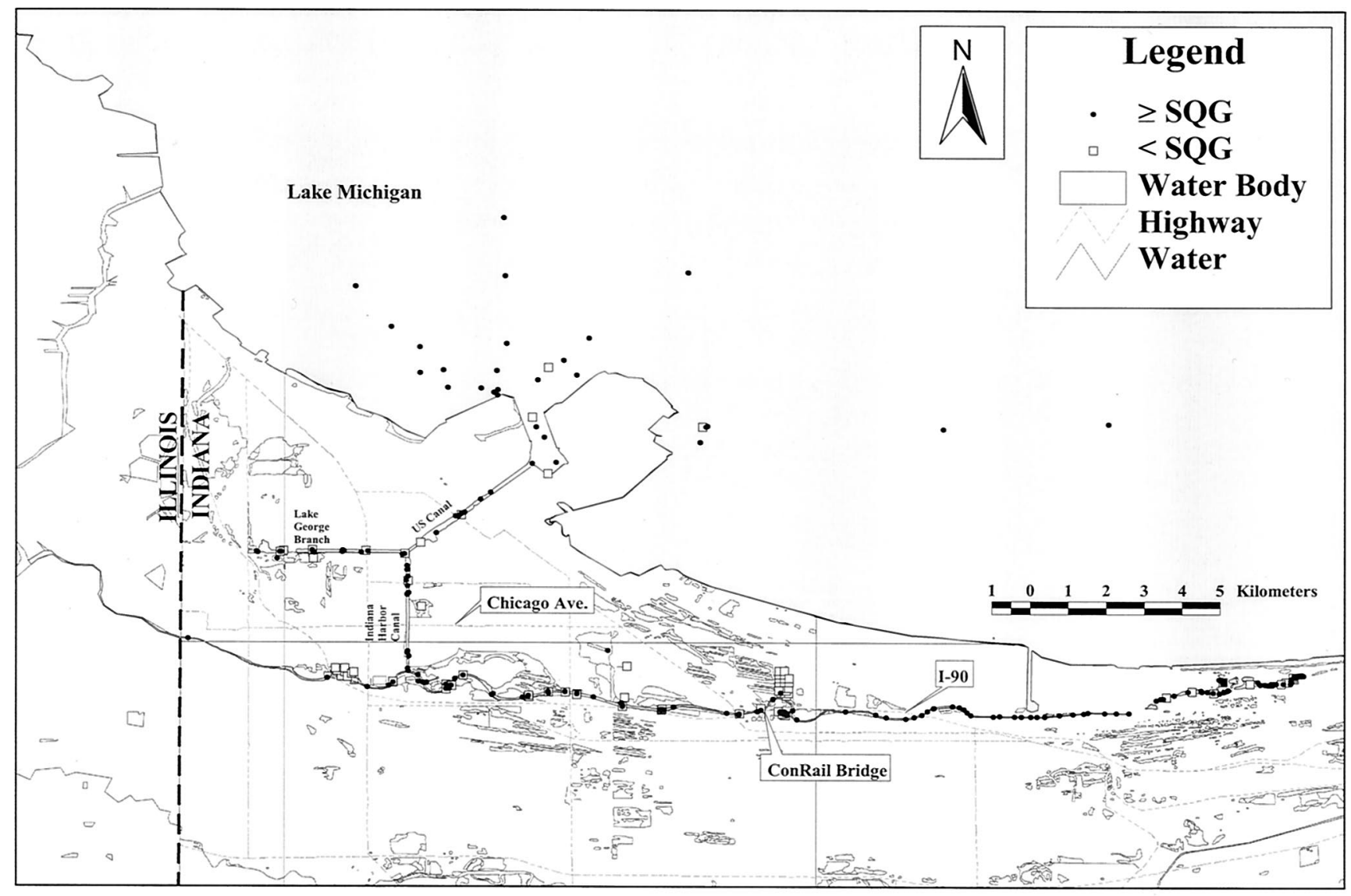

Fig. 2. Extent of injury to fish and wildlife resources, based on comparisons of sediment chemistry data to bioaccumulation-based SQGs (NYSDEC 1999; one or more exceedance of the SQGs is considered to be indicative of injury to fish and wildlife resources)

stances were compared to bioaccumulation-based SQGs for the protection of wildlife (NYSDEC 1999). The results of this evaluation demonstrated that the concentrations of various sediment-associated contaminants were sufficient to adversely affect fish and wildlife species that utilize habitats within the GCR watershed (i.e., through bioaccumulation of contaminants in sediment-dwelling organisms and subsequent food web transfer to wildlife species, such as osprey). Overall, $74 \%$ of the sediment samples (i.e., 295 of 396 samples) had elevated levels of one or more bioaccumulative contaminants (i.e., PCBs, organochlorine pesticides, and/or dioxins). Among the various reaches, the frequency of exceedance of one or more of the bioaccumulation-based SQGs ranged from $18 \%$ to $93 \%$ of the sediment samples (Table 1), indicating that all of the reaches have levels of bioaccumulative substances in sediments that are sufficient to cause or substantially contribute to adverse effects to fish and wildlife resources. The levels of total PCBs, total chlordane, total DDTs, endrin, heptachlor, heptachlor epoxide, and lindane exceeded the bioaccumulation-based SQGs in many samples with the highest frequency of exceedance observed for PCBs (258 of 269 samples; 96\%; Table 4). Such bioaccumulation SQGs were not available for metals or PAHs, which precluded an evaluation of the potential for bioaccumulation of these chemical classes.

Tissue chemistry data provide direct information for deter- mining if bioaccumulative substances pose unacceptable hazards to fish and wildlife species. In this investigation, the measured concentrations of bioaccumulative substances in the tissues of fish and other aquatic organisms (i.e., benthic invertebrates) were compared to the TRGs that have been established for the protection of fish-eating wildlife species (Newell et al. 1987). The results of this evaluation indicate that tissue residue levels in fish and invertebrates from the assessment area frequently exceed the TRGs for piscivorus wildlife. Overall, 100 of 103 tissue samples (97\%) had elevated levels of one or more bioaccumulative substances (Table 1). One or more of the TRGs were exceeded in $100 \%$ of the samples in all the reaches except the LGB (insufficient data) and IH/LM (86\%; 18 of 21 samples). Based on the frequency of exceedance of the TRGs (130 of 136 samples; 96\%; Table 5), total PCBs represented the primary bioaccumulative $\mathrm{COC}$ in the tissues of aquatic organisms. Nevertheless, total chlordane, endrin, dieldrin + aldrin, and total DDTs were also measured at elevated levels in $2 \%$ to $24 \%$ of fish and invertebrate tissues from the assessment area (Table 5).

In this investigation, five lines of evidence were used to assess sediment injury relative to fish and wildlife resources. Overall, the results of this assessment indicate that conditions in all nine reaches are sufficient to adversely affect fish and wildlife resources (Table 1). More specifically, sediments from 
Table 2. Summary of DELT (\% incidence of deformities, fin erosion, lesions, and tumors) scores for the various reaches in the assessment area, 1993-1998 (from Sobiech et al. 1994; Simon and Stewart 1998; Simon et al. 2000; Simon 1993)

\begin{tabular}{|c|c|c|c|c|c|c|c|c|c|c|}
\hline \multirow[b]{2}{*}{$\begin{array}{l}\text { Sampling } \\
\text { Date }\end{array}$} & \multirow[b]{2}{*}{$\begin{array}{l}\text { Sample } \\
\text { Number }\end{array}$} & \multicolumn{9}{|c|}{ Reach of Assessment Area } \\
\hline & & $\begin{array}{l}\text { Grand } \\
\text { Calumet } \\
\text { Lagoons }\end{array}$ & $\begin{array}{l}\text { East Branch } \\
\text { Grand } \\
\text { Calumet } \\
\text { River-I }\end{array}$ & $\begin{array}{l}\text { East Branch } \\
\text { Grand } \\
\text { Calumet } \\
\text { River-II }\end{array}$ & $\begin{array}{l}\text { West Branch } \\
\text { Grand } \\
\text { Calumet } \\
\text { River-I }\end{array}$ & $\begin{array}{l}\text { West Branch } \\
\text { Grand } \\
\text { Calumet } \\
\text { River-II }\end{array}$ & $\begin{array}{l}\text { Indiana } \\
\text { Harbor } \\
\text { Canal }\end{array}$ & $\begin{array}{l}\text { Lake } \\
\text { George } \\
\text { Branch }\end{array}$ & US Canal & $\begin{array}{l}\text { Indiana } \\
\text { Harbor/ } \\
\text { Lake } \\
\text { Michigan }\end{array}$ \\
\hline \multirow[t]{12}{*}{ October 1993} & 1 & 0 & & & & & & & & \\
\hline & 2 & 0 & & & & & & & & \\
\hline & 3 & 0 & & & & & & & & \\
\hline & 4 & 0 & & & & & & & & \\
\hline & 5 & 0 & & & & & & & & \\
\hline & 6 & 0 & & & & & & & & \\
\hline & 7 & 0 & & & & & & & & \\
\hline & 8 & 0 & & & & & & & & \\
\hline & 9 & 0 & & & & & & & & \\
\hline & 10 & 0 & & & & & & & & \\
\hline & 11 & 0 & & & & & & & & \\
\hline & 12 & 0 & & & & & & & & \\
\hline \multirow{4}{*}{$\begin{array}{c}\text { June-July } \\
1994\end{array}$} & 1 & & 2.7 & 5.6 & & & & & & \\
\hline & 2 & & & 8.0 & & & & & & \\
\hline & 3 & & & 17.4 & & & & & & \\
\hline & 4 & & & 0 & & & & & & \\
\hline $\begin{array}{c}\text { September } \\
1992\end{array}$ & 1 & & & & 10.8 & & & & & \\
\hline \multirow[t]{9}{*}{1998} & 1 & & 0 & & 6.15 & 2.8 & 6.15 & 1.68 & 0 & 12.8 \\
\hline & 2 & & 0.74 & & 2.8 & & 0 & 0 & 3.28 & \\
\hline & 3 & & 1.57 & & & & 0.36 & & & \\
\hline & 4 & & 0 & & & & & & & \\
\hline & 5 & & 0.65 & & & & & & & \\
\hline & 6 & & 0.7 & & & & & & & \\
\hline & 7 & & 0.15 & & & & & & & \\
\hline & 8 & & 2.4 & & & & & & & \\
\hline & 9 & & 6.15 & & & & & & & \\
\hline $\begin{array}{c}\text { Average } \\
\text { DELT } \\
\text { score }\end{array}$ & & 0 & 1.5 & 7.8 & 6.6 & 2.8 & 2.2 & 0.8 & 1.6 & 12.8 \\
\hline $\mathrm{SD}$ & & NA & 1.89 & 7.25 & 4.02 & NA & 3.45 & 1.19 & 2.32 & NA \\
\hline $\begin{array}{c}\text { Number of } \\
\text { samples }\end{array}$ & & 12 & 10 & 4 & 3 & 1 & 3 & 2 & 2 & 1 \\
\hline
\end{tabular}

$\mathrm{NA}=$ Not applicable.

several reaches of the assessment area have been demonstrated to be toxic to fish (Table 1). In addition, fish health has been compromised in three of the reaches of the assessment area (Table 2). As would be expected in areas that have impaired fish health and toxic conditions, the integrity of fish communities within the assessment area is generally poor to very poor (as measured using IBI scores; Table 3). Finally, the available sediment chemistry data indicate that the concentrations of bioaccumulative substances are high enough to pose hazards to wildlife (i.e., as a result of bioaccumulation in the sedimentdwelling organisms and subsequent food web transport to piscivorus wildlife species; Table 1). The available data on tissue chemistry confirm that bioaccumulation is occurring within the assessment area and that the concentrations of bioaccumulative substances in the tissues of aquatic organisms are sufficient to adversely affect fish-eating wildlife species (Table 1; MacDonald and Ingersoll 2000a).

There was a high level of concordance between the five indicators of adverse effects on fish and wildlife resources. In four of the reaches, EBGCR-I, EBCGR-II, WBGCR-I, and WBGCR-II, four or five lines of evidence indicated that conditions sufficient to adversely affect fish and wildlife resources were encountered within the assessment area. In the GCL, IHC, and USC, adverse effects on fish and wildlife resources was indicated by three lines of evidence. The assessment of adverse effects on fish and wildlife resources in the LGB (one line of evidence) and IH/LM (two lines of evidence) was restricted by limitations on the available data, particularly with respect to sediment toxicity to fish and tissue chemistry. Nevertheless, injury to fish and wildlife resources has been demonstrated (i.e., one or more lines of evidence) throughout the assessment area.

\section{COCs}

Based on the results of this assessment total PCBs is the primary bioaccumulative $\mathrm{COC}$ identified in the assessment area 
Table 3. Summary of IBI scores for the various reaches in the assessment area, 1985-1998 (from Sobiech et al. 1994; Simon and Stewart 1998; Simon 1993; Stewart et al. 1999; Simon et al. 2000)

\begin{tabular}{|c|c|c|c|c|c|c|c|c|c|c|}
\hline \multirow[b]{2}{*}{ Sampling Date } & \multirow[b]{2}{*}{$\begin{array}{l}\text { Sample } \\
\text { Number }\end{array}$} & \multicolumn{9}{|c|}{ Reach of Assessment Area } \\
\hline & & $\begin{array}{l}\text { Grand } \\
\text { Calumet } \\
\text { Lagoons }\end{array}$ & $\begin{array}{l}\text { East Branch } \\
\text { Grand } \\
\text { Calumet } \\
\text { River-I }\end{array}$ & $\begin{array}{l}\text { East Branch } \\
\text { Grand } \\
\text { Calumet } \\
\text { River-II }\end{array}$ & $\begin{array}{l}\text { West Branch } \\
\text { Grand } \\
\text { Calumet } \\
\text { River-I }\end{array}$ & $\begin{array}{l}\text { West Branch } \\
\text { Grand } \\
\text { Calumet } \\
\text { River-II }\end{array}$ & $\begin{array}{l}\text { Indiana } \\
\text { Harbor } \\
\text { Canal }\end{array}$ & $\begin{array}{l}\text { Lake } \\
\text { George } \\
\text { Branch }\end{array}$ & US Canal & $\begin{array}{l}\text { Indiana } \\
\text { Harbor/ } \\
\text { Lake } \\
\text { Michigan }\end{array}$ \\
\hline \multirow[t]{2}{*}{ October 1985} & 1 & & 24 & 24 & & 24 & & & & \\
\hline & 2 & & 24 & & & 0 & & & & \\
\hline \multirow[t]{2}{*}{ June 1986} & 1 & 32 & 24 & 26 & 22 & 22 & & & 24 & \\
\hline & 2 & & 24 & 24 & & & & & & \\
\hline \multirow[t]{2}{*}{ October 1986} & 1 & & 30 & 28 & 20 & 20 & & & 26 & \\
\hline & 2 & & 28 & 28 & & & & & & \\
\hline \multirow[t]{3}{*}{ April 1987} & 1 & & 22 & 30 & 24 & 24 & 22 & & & \\
\hline & 2 & & 22 & 32 & 22 & 24 & & & & \\
\hline & 3 & & 22 & 24 & & & & & & \\
\hline \multirow[t]{2}{*}{ April 1987} & 1 & & 24 & 24 & 22 & 22 & & & 28 & \\
\hline & 2 & & 26 & 26 & & & & & & \\
\hline \multirow[t]{2}{*}{ November 1987} & 1 & & 30 & 32 & 0 & 0 & & & 34 & \\
\hline & 2 & & 30 & 30 & & & & & & \\
\hline \multirow[t]{2}{*}{ May 1988} & 1 & & 22 & 26 & 0 & 0 & & & & \\
\hline & 2 & & 24 & 24 & & & & & & \\
\hline \multirow[t]{2}{*}{ July 1988} & 1 & & 32 & 28 & 0 & 0 & & & 24 & \\
\hline & 2 & & 26 & 26 & & & & & & \\
\hline \multirow[t]{2}{*}{ July 1990} & 1 & & 20 & 24 & 21 & 21 & & & 16 & \\
\hline & 2 & & 32 & 32 & & & & & & \\
\hline \multirow[t]{5}{*}{ September 1992} & 1 & & & & 29 & 24 & & & & \\
\hline & 2 & & & & & 24 & & & & \\
\hline & 3 & & & & & 12 & & & & \\
\hline & 4 & & & & & 12 & & & & \\
\hline & 5 & & & & & 19 & & & & \\
\hline \multirow[t]{4}{*}{ June 1994} & 1 & & 22 & 12 & & & & & & \\
\hline & 2 & & & 18 & & & & & & \\
\hline & 3 & & & 22 & & & & & & \\
\hline & 4 & & & 22 & & & & & & \\
\hline \multirow[t]{12}{*}{1994} & 1 & 42 & & & & & & & & \\
\hline & 2 & 42 & & & & & & & & \\
\hline & 3 & 42 & & & & & & & & \\
\hline & 4 & 34 & & & & & & & & \\
\hline & 5 & 32 & & & & & & & & \\
\hline & 6 & 31 & & & & & & & & \\
\hline & 7 & 38 & & & & & & & & \\
\hline & 8 & 32 & & & & & & & & \\
\hline & 9 & 43 & & & & & & & & \\
\hline & 10 & 43 & & & & & & & & \\
\hline & 11 & 42 & & & & & & & & \\
\hline & 12 & 42 & & & & & & & & \\
\hline \multirow[t]{3}{*}{1998} & 1 & & 16 & & 16 & 22 & 16 & 14 & 12 & 14 \\
\hline & 2 & & 22 & & 22 & & 12 & 38 & 18 & \\
\hline & 3 & & 16 & & & & 20 & & & \\
\hline 1998 & 4 & & 18 & & & & & & & \\
\hline & 5 & & 20 & & & & & & & \\
\hline & 6 & & 24 & & & & & & & \\
\hline & 7 & & 24 & & & & & & & \\
\hline & 8 & & 26 & & & & & & & \\
\hline & 9 & & 18 & & & & & & & \\
\hline $\begin{array}{l}\text { Average IBI } \\
\text { score }\end{array}$ & & 38.1 & 23.9 & 25.5 & 16.5 & 15.9 & 17.5 & 26.0 & 22.8 & 14.0 \\
\hline $\mathrm{SD}$ & & 5.0 & 4.3 & 4.7 & 10.4 & 9.8 & 4.4 & 17.0 & 7.1 & NA \\
\hline $\begin{array}{c}\text { Number of } \\
\text { samples }\end{array}$ & & 13 & 29 & 22 & 12 & 17 & 4 & 2 & 8 & 1 \\
\hline Percent altered & & & 100 & 100 & 100 & 100 & 100 & 50 & 100 & 100 \\
\hline $\begin{array}{l}\text { Classification for } \\
\text { average score }\end{array}$ & & fair-poor & $\begin{array}{l}\text { poor-very } \\
\text { poor }\end{array}$ & $\begin{array}{l}\text { poor-very } \\
\text { poor }\end{array}$ & very poor & very poor & very poor & $\begin{array}{l}\text { poor-very } \\
\text { poor }\end{array}$ & $\begin{array}{l}\text { poor-very } \\
\text { poor }\end{array}$ & very poor \\
\hline
\end{tabular}


Table 4. Summary of the available data on the concentrations of bioaccumulative substances (in $\mu \mathrm{g} / \mathrm{kg}$ organic carbon) in assessment area sediments (MacDonald and Ingersoll 2000b).

\begin{tabular}{|c|c|c|c|c|c|c|}
\hline Substance & $\mathrm{n}$ & Mean & SD & Range & $\mathrm{SQG}^{\mathrm{a}}$ & $\begin{array}{l}\text { Number of Exceedances } \\
\text { of SQGs }(\%)\end{array}$ \\
\hline \multicolumn{7}{|c|}{ Polychlorinated biphenyls } \\
\hline Total PCBs & 269 & 337,000 & $1,020,000$ & 7.86-12,700,000 & 1,400 & $258(96 \%)$ \\
\hline \multicolumn{7}{|c|}{ Organochlorine pesticides } \\
\hline Total DDTs & 159 & 27,400 & 223,000 & $62.0-2,790,000$ & 1,000 & $65(41 \%)$ \\
\hline Chlordane & 51 & 4,790 & 7,020 & $106-38,100$ & 6 & $51(100 \%)$ \\
\hline Endrin & 145 & 224 & 436 & $12.6-4,340$ & 800 & $4(3 \%)$ \\
\hline Heptachlor & 30 & 3,180 & 7,080 & $10.1-36,900$ & 30 & $18(60 \%)$ \\
\hline Heptachlor epoxide & 27 & 1,780 & 4,950 & $10.1-25,700$ & 30 & $16(59 \%)$ \\
\hline Lindane & 246 & 506 & 2,100 & $10.1-25,400$ & 1,500 & $10(4 \%)$ \\
\hline \multicolumn{7}{|l|}{ Dioxins/furans } \\
\hline $2,3,7,8-\mathrm{TCDD}^{\mathrm{b}}$ & 2 & 0.886 & 1.15 & $0.0735-1.70$ & 0.2 & $1(50 \%)$ \\
\hline
\end{tabular}

${ }^{\mathrm{a}} \mathrm{SQG}=$ Bioaccumulation-based sediment quality guideline (from NYSDEC 1999).

b $2,3,7,8$-TCDD $=2,3,7,8$-tetrachlorodibenzodioxin.

Table 5. Summary of the available data on the concentrations of bioaccumulative substances ( $\mu \mathrm{g} / \mathrm{kg}$ wet weight) in fish and invertebrate tissues from the assessment area (MacDonald and Ingersoll 2000b)

\begin{tabular}{|c|c|c|c|c|c|c|}
\hline Substance & $\mathrm{n}$ & Mean & SD & Range & $\mathrm{TRG}^{\mathrm{a}}$ & $\begin{array}{l}\text { Number of Exceedances } \\
\text { of TRGs }(\%)\end{array}$ \\
\hline \multicolumn{7}{|c|}{ Polychlorinated biphenyls } \\
\hline Total PCBs & 136 & 2,530 & 4,130 & $15.1-27,100$ & 110 & $130(96 \%)$ \\
\hline \multicolumn{7}{|c|}{ Organochlorine pesticides } \\
\hline Total DDTs & 63 & 282 & 542 & $11-3,350$ & 200 & $15(24 \%)$ \\
\hline Chlordane & 62 & 48.0 & 72.5 & $8-442$ & 370 & $1(2 \%)$ \\
\hline Endrin & 37 & 6.82 & 7.22 & $5-41$ & 25 & $2(5 \%)$ \\
\hline $\begin{array}{l}\text { Heptachlor and } \\
\text { Heptachlor Epoxi }\end{array}$ & 39 & 7.76 & 3.87 & $4-24$ & 25 & $0(0 \%)$ \\
\hline Lindane & 37 & 4.93 & 1.99 & $3-13$ & 100 & $0(0 \%)$ \\
\hline Mirex & 11 & 5 & - & $5-5$ & 330 & $0(0 \%)$ \\
\hline Dieldrin and aldrin & 40 & 23.0 & 39.8 & 5-207 & 22 & $8(20 \%)$ \\
\hline
\end{tabular}

${ }^{\mathrm{a}} \mathrm{TRG}=$ Tissue residue guideline (from Newell et al. 1987).

(MacDonald and Ingersoll 2000a). Total PCBs frequently exceeded chemical benchmarks in surficial and subsurface sediments and/or in tissues throughout the assessment area (Tables 4 and 5). In addition, the concentrations of total PCBs in sediments often exceeded the chemical benchmarks by a substantial margin (i.e., by up to a factor of 247). Therefore, total PCBs were present in whole sediment and tissues at concentrations that are sufficient to adversely affect fish and wildlife resources. It is important to note, however, that this assessment was restricted by the availability of published bioaccumulationbased SQGs, TRGs, and other benchmarks of sediment quality conditions. The availability of chemistry data for tissues also restricted this assessment in certain reaches of the assessment area. Furthermore, insufficient information was located to facilitate identification of the substances that are causing or substantially contributing to effects on fish (i.e., sediment toxicity, impaired fish health, or impaired fish community structure). Therefore, substances not included on the list of COCs can not necessarily be considered to be of low priority with respect to sediment injury (e.g., metals, PAHs, alkanes, alkenes, organochlorine pesticides, phthalates, dioxins, and furans, etc.).

\section{Summary}

An evaluation of injury associated with contaminated sediments was conducted in the assessment area. To support this evaluation, the assessment area was divided into nine reaches: GCL, EBGCR-I, EBGCR-II, WBGCR-I, WBGCR-II, IHC, LGB, USC, and IH/LM. The results of this evaluation demonstrate that sediments throughout the assessment area have been injured due to discharges of oil or releases of other hazardous substances. This conclusion is supported by up to five of the following separate lines of evidence (Table 1).

- Whole sediments, pore water, or elutriates from the assessment area were frequently toxic to fish

- The health of fish in the assessment area, as indicated by an elevated incidence of DELT abnormalities, has been compromised relative to fish utilizing aquatic habitats elsewhere in the Central Corn Belt Plain ecoregion

- The integrity of fish communities in the assessment area has frequently been degraded relative to reference sites in the Central Corn Belt Plain ecoregion

- Concentrations of total PCBs and other bioaccumulative 
substances in sediments frequently exceeded the bioaccumulation-based SQGs for the protection of wildlife

- Concentrations of total PCBs and other bioaccumulative substances in the tissues of aquatic organisms frequently exceeded the TRGs for the protection of wildlife

Any one of these lines of evidence could be used alone to support the conclusion that sediment injury has occurred in the assessment area. When considered together, however, these five separate lines of evidence provide a weight of evidence for concluding that discharges of oil or releases of other hazardous substances have created conditions that are sufficient to adversely affect fish and wildlife resources. Total PCBs and other bioaccumulative substances are present in assessment area sediments and tissues at concentrations sufficient to cause or substantially contribute to the injury of fish and wildlife resources.

This investigation was conducted to document the impact of oil and other hazardous substances on the resources of the assessment area (i.e., injury determination). With the completion of the injury determination phase of the assessment, it is anticipated that the Natural Resource Trustees will proceed to the injury quantification phase to determine the loss or impairment of specific natural resource services (e.g., provision of habitat for biological resources) that are associated with injury to sediments and sediment-dwelling organisms. In the final step of the NRDA process, the trustees will determine the type and magnitude of compensation required to restore injured natural resources to appropriate baseline conditions and to address the public's loss of natural resource services for the period preceding restoration to baseline (Natural Resources Trustees 1997). Collectively, the results of the various components of the NRDA will support decisions regarding the restoration of natural resources within the assessment area.

Acknowledgments. The authors would like to acknowledge a number of individuals who contributed to the production of this manuscript, including Pam Haverland (U.S. Geological Survey), Ning Wang (University of Missouri), Jeff Loiter, John Weiss (Industrial Economics), Jim Stahl, Ronda DuFour, Jeff Ewick, Roger Koelpin (Indiana Department of Environmental Management), Sreedevi Yedavalli (U.S Environmental Protection Agency), and Tadd Berger. The authors would also like to thank seven anonymous reviewers for conducting thorough peer reviews of this manuscript. The preparation of this article was supported in part by funding provided by U.S. Wildlife Service, National Research Council of Canada, Canadian Council for Human Resources and the Environment Industry, and British Columbia Information, Science and Technology Agency. The views expressed herein are those of the authors and do not necessarily reflect the views of the U.S. Fish and Wildlife Service, the U.S. Geological Survey, or the Indiana Department of Environmental Management.

\section{References}

ASTM (American Society for Testing and Materials) (2001) Standard guide for conducting early life-stage toxicity tests with fishes. E1706, ASTM 2001 annual book of standards, vol. 11.05, West Conshohocken, PA

Brannon JM, Gunnison D, Averett DE, Martin JL, Chen RL, Athow
RF (1989) Analysis of impacts of bottom sediments from Grand Calumet River and Indiana Harbor Canal on water quality. Report Number D-89-1, Waterways Experiment Station, U.S. Army Corps of Engineers, Vicksburg, MS

Bright GR (1988) Recent water quality in the Grand Calumet River as measured by benthic invertebrates. Proc IN Acad Sci 98:229-233

Burton A (1994) West Branch Grand Calumet River: 1993 sediment toxicity test data summaries. Prepared for Environmental Sciences Division, U.S. Environmental Protection Agency, Region V, Chicago, IL

CCME (Canadian Council of Ministers of the Environment) (1999) Canadian environmental quality guidelines. Guidelines and Standards Division, Environment Canada, Winnipeg, MB

Gillespie RB, Speelman J, Stewart PM (1998) An evaluation of the toxic effects of sediments in the Grand Calumet Lagoons near the Indiana Dunes National Lakeshore. Water Resource Division, National Park Service, Fort Collins, CO, 45 pp

Goyette D, Brand D, Thomas M (1988) Prevalence of idiopathic liver lesions in English sole and epidermal abnormalities in flatfish from Vancouver Harbour, British Columbia, 1986. Regional Program Report 87-09, Environment Canada, Vancouver, BC, 48 pp

IDEM (Indiana Department of Environmental Management) (2000) Indiana water quality report. Office of Water Management, Planning and Restoration Branch, Indianapolis, IN

IJC (International Joint Commission) (1989) Report on Great Lakes water quality. Great Lakes Water Quality Board, Windsor, ON

Ingersoll CG, Dillon T, Biddinger RG (eds) (1997) Ecological risk assessments of contaminated sediment. SETAC Press, Pensacola, FL, $389 \mathrm{pp}$

Lucas AM, Steinfeld JD (1972) Toxicity studies of Grand Calumet River sediments-September, 1972. Water Sciences Branch, U.S. Environmental Protection Agency, Cincinnati, OH, $16 \mathrm{pp}$

MacDonald DD, Ingersoll CG (2000a) An assessment of sediment injury in the Grand Calumet River, Indiana Harbor Canal, Indiana Harbor, and the nearshore areas of Lake Michigan, vol. I. Prepared for the U.S. Fish and Wildlife Service, Bloomington, IN

MacDonald DD, Ingersoll CG (2000b) An assessment of sediment injury in the Grand Calumet River, Indiana Harbor Canal, Indiana Harbor, and the nearshore areas of Lake Michigan, vol. IVappendices. Prepared for the U.S. Fish and Wildlife Service, Bloomington, IN

MacDonald DD, Ingersoll CG, Berger TA (2000) Development and evaluation of consensus-based sediment quality guidelines for freshwater ecosystems. Arch Environ Contam Toxicol 39:20-31

MacDonald DD, Ingersoll CG, Smorong DE, Lindskoog RA, Sparks DW, Smith JR, Simon TP, Hanacek MA (2002) An assessment of injury to sediments and sediment-dwelling organisms in the Grand Calumet River and Indiana Harbor Area of Concern. Arch Environ Contam Toxicol (this issue)

Malins DC, Krahn MM, Myers MS, Rhodes LD, Brown DW, Krone CA, McCain BB, Chan S-L (1985) Toxic chemicals in sediments and biota from a creosote-polluted harbor: relationships with hepatic neoplasms and other hepatic lesions in English sole (Parophrys vetulus). Carcinogenesis 6(10):1463-1469

Natural Resources Trustees (1997) Assessment plan for the natural resource damage assessment of the Grand Calumet River, Indiana Harbor Ship Canal, Indiana Harbor, and associated Lake Michigan environments. Prepared for U.S. Department of Interior and the State of Indiana, Indianapolis, IN

Newell AJ, Johnson DW, Allen LK (1987) Niagara River biota contamination project: fish flesh criteria for piscivorus wildlife. Technical Report 87-3, New York State Department of Environmental Conservation, Albany, NY, 182 pp

NYSDEC (New York State Department of Environmental Conservation) (1999) Technical guidance for screening contaminated sediments. Division of Fish, Wildlife, and Marine Resources, Albany, NY, $39 \mathrm{pp}$ 
OEPA (Ohio Environmental Protection Agency) (1988) Biological criteria for the protection of aquatic life, Volume II: users manual for biological field assessment of Ohio surface waters. Ecological Assessment Section, Division of Water Quality Planning and Assessment, Columbus, $\mathrm{OH}$

Payne JF, Kiceniuk J, Fancey LL, Williams U, Fletcher GL, Rahimtula A, Fowler B (1988) What is a safe level of polycyclic aromatic hydrocarbons for fish: subchronic toxicity study of winter flounder (Pseudopleuronectes americanus). Can J Fish Aquat Sci 45:19831993

Ryder K (1993) Preliminary inventory of industries on the Grand Calumet River, Indiana and Illinois. Environmental and Social Analysis Branch, Chicago District, U.S. Army Corps of Engineers, Chicago, IL

Simon TP (1991) Development of expectations for the ecoregions of Indiana-Central Corn Belt Plain, vol. 1. Prepared for Environmental Sciences Division, U.S. Environmental Protection Agency, Region V, Chicago, IL

Simon TP (1993) Biological characterization of the West Branch of the Grand Calumet River, East Chicago and Hammond, Indiana, and Burnham, Illinois, using fish community attributes, 21. Prepared for Water Quality Branch, U.S. Environmental Protection Agency, Region V, Chicago, IL

Simon TP, Moy PB (1997) Fishes. In: Whitman RL, Moy PB (eds) Grand Calumet River-Indiana Harbor Canal sediment cleanup and restoration alternatives project. Chicago District, U.S. Army Corps of Engineers, Chicago, IL

Simon TP, Stewart PM (1998) Application of an index of biotic integrity for dunal, palustrine wetlands: emphasis on assessment of nonpoint source landfill effects on the Grand Calumet lagoons. Aquat Eco Health Manag 1:63-74
Simon TP, Bright GR, Rud J, Stahl J (1989) Water quality characterization of the Grand Calumet River basin using the index of biotic integrity. Proc IN Acad Sci 98:257-265

Simon TP, Sparks D, Newhouse S, Dufour R (2000) Aquatic community injury assessment for the Grand Calumet River, Indiana Harbor Canal, and the nearshore areas of Lake Michigan. Natural resource damage assessment. U.S. Fish and Wildlife Service, Bloomington, IN

Sobiech SA, Simon TP, Sparks DW (1994) Pre-remedial biological and water quality assessment of the East Branch Grand Calumet River, Gary, Indiana. Prepared for U.S. Environmental Protection Agency, Region V, Chicago, IL; prepared by U.S. Fish and Wildlife Service, Bloomington, IN, $111 \mathrm{pp}$

Stewart PM, Butcher JT, Simon TP (1999) Ecological assessment of the Grand Calumet lagoons and adjacent ponds: water quality, aquatic communities, sediment contaminants, and toxicity testing. Prepared for the National Park Service, Water Resources Division and the Indiana Dunes National Lakeshore, U.S. Geological Survey

US DOI (US Department of the Interior) (1996) Natural Resource Damage Assessment regulations. Authorized under CERCLA (Comprehensive Environmental Response, Compensation, and Liability Act) 1980, as amended under Superfund Amendments and Reauthorization Act, 1986. 43 CFR, Part 11 (1995), as amended at 61 Federal Register 20559-20614, May 7, 1996

US EPA (US Environmental Protection Agency) (2000) Methods for measuring the toxicity and bioaccumulation of sedimentassociated contaminants with freshwater invertebrates, $2 \mathrm{~d}$ ed. EPA-600-R99-064, Office of Research and Development, Washington, DC 


\section{COPYRIGHT INFORMATION}

TITLE: Assessment of injury to fish and wildlife resources in the Grand Calumet River and Indiana Harbor Area of Concern, USA

SOURCE: Arch Environ Contam Toxicol 43 no2 Ag 2002

The magazine publisher is the copyright holder of this article and it is reproduced with permission. Further reproduction of this article in violation of the copyright is prohibited. To contact the publisher:

http://www.springerlink.com/content/1432-0703/ 